\title{
COLCHICINE-INDUCED MUTAGENESIS FOR IMPROVED GROWTH AND YIELD OF FONIO (Digitaria exilis [Kippist] Stapf.)
}

\author{
${ }^{*}$ Nura, S., ${ }^{1}$ Adamu, A.K., ${ }^{2}$ Adelanwa, M.A., ${ }^{2}$ Usman, I.S., ${ }^{3}$ and Shehu, K. $^{4}$ \\ 1. Department of Biology, Ahmadu Bello University Zaria, Nigeria. \\ 2. Department of Botany, Ahmadu Bello University Zaria, Nigeria. \\ 3. Department of Plant Science, Ahmadu Bello University Zaria, Nigeria. \\ 4. Department of Biological Science, Police Academy, Kano, Nigeria. \\ *Corresponding Author: salisunura40@yahoo.com
}

\begin{abstract}
The effect of colchicine on some growth and yield parameters of fonio (Digitaria exilis) was studied. Seeds of five accessions of fonio (Dinat, Jakah, Jiw 1, Jiw 2 and Nkpowas) were treated with five different colchicine concentrations $(0.1 \mathrm{mM}, 0.5 \mathrm{mM}, 1.0 \mathrm{mM}, 2.0 \mathrm{mM}$ and $0.0 \mathrm{mM}$ as control) via soaking with the aim of inducing variability that could be exploited in the improvement of the crop. The treated seeds were sown in a plot in a Completely Randomized Design with three replications in a factorial arrangement. The result obtained revealed highly significant difference $(P \leq 0.01)$ in the effects of different concentrations of colchicine on the growth and yield components of fonio. The result showed that colchicine produced taller mutants $(79-83.93 \mathrm{~cm})$ with many leaves (10-14 leaves) that are larger in cross sectional area (11.35-13.15 $\left.\mathrm{cm}^{2}\right)$. More so, the mutants produced high tiller number with high number of spikes that are longer and bear high number of seeds/spikes. Similarly the 1000 mutants' seeds weight is higher than that of the controls. The effect of the mutagen is concentration dependent, decrease with increase in concentrations. Lower colchicine concentration ( $0.1 \mathrm{mM})$ and accession Jiw 1 having highest responses to colchicines treatment was recommended for breeding programs in fonio.
\end{abstract}

Key Words: Colchicine. Concentrations, Fonio, Mutation

\section{INTRODUCTION}

Fonio (Digitaria exilis [Kippist] Stapf.) known popularly as Acha, fundi, findi, petit mil or hungry rice (Jideani, 1999 ) is one of the oldest African cereal cultivated for thousands of years; since about 5000 B.C (Chukwu and Abdulqadir, 2008). It is cultivated across the West African dry savannas from Senegal to Cameroun. There are over 300 Digitaria species which are sometimes grown as fodder; out of which only three or four are sometimes grown as cereals (CIRAD, 2004). Indeed, it was a staple food crop on the Fouta Djallon in Guinea and the Bauchi plateau in Nigeria (Purseglove, 1972). Fonio grains are the best tasting and nutritious of all grains known to man (Vietmeyer et al., 1996) with about $7 \%$ crude protein that is high in leucine $(9.8 \%)$, methionine (5.6\%) and valine $(5.8 \%)$ (Temple and Bassa, 1991). Diverse biochemical investigations indicated that the nutritive value of fonio grain is favorably comparable with that of other cereals (Haq and Ogbe, 1995) and was proved to have possessed excellent protein composition (9-12\%) rich in methionine and cystine, two vital amino-acids almost deficient in the major cereals like sorghum, rice, wheat or barley (Barikmo and Ouattara, 2004; IPGRI, 2004). More so, the concentrations of methionine, cysteine and leucine in fonio are slightly higher than those defined for the Food and Agriculture Organization reference protein (Temple and Bassa, 1991). Fonio species contain less polyphenols with high digestibility of protein (Jideani et al., 1994; Jideani and Podgorski, 2009). Fonio is among the world's best tasting cereals and has a high diversity of uses in human consumption (Vietmeyer et al., 1996). In many African countries, fonio is traditionally cooked as couscous, various porridges and dishes and as local beverages (Adoukonou et al., 2006). Fonio is traditionally consumed whole as tuo (tuwo), djouka, couscous, gwete, acha jollof and kunun acha (Jideani, 1993) in Nigeria.

However, despite all the tremendous benefits of fonio to human endeavor, it is generally unimproved and its cultivation is not beyond subsistence level in Nigeria. There is neglect from the authorities concerned as there is no single variety registered in the country. Farmers grow traditional landraces with poor yields. Mutations (changes in the genetic materials of an organism) are known to enhance the genetic variability of crop plants. Induced mutations facilitate the development of improved varieties (Maluszynski, 1990). Induced mutations have been used to generate genetic variability and have been successfully utilized to improve yield components of various crops (Naik and Murthy, 2009). 
It provides raw materials for the genetic improvement of economic crops (Adamu et al., 2004) by facilitating the isolation, identification and cloning of genes which would ultimately help in designing crops with improved yield, increased stress tolerance and longer life span with reduced agronomic in-puts (Ahloowalia and Maluszynski, 2001). Colchicine, a poisonous alkaloid from autumn crocus (Colchicum autumnale) has been used since 1937 in plant breeding work to produce changes in plants by improving growth and yield components. This research therefore used various colchicine concentrations to improve the growth and yield components of fonio.

\section{MATERIALS AND METHODS Study Site}

The research was conducted at the Botanical Garden of the Department of Biological Sciences, Ahmadu Bello University, Zaria, located within the tropical guinea savanna zone of Nigeria (Lat $11^{\circ} 11^{\prime} \mathrm{N}$; Long $7^{\circ} \mathrm{N} 38^{\prime} \mathrm{E}$ and on alt $660 \mathrm{~m}$ above sea level) during the 2015 wet season.

\section{Sources of the Seeds}

Seeds of five different accessions of fonio (Dinat, Jakah, Jiw 1, Jiw 2 and Nkpowas) used were obtained from the National Cereal Research Institute, Badeggi, Niger state.

\section{Treatment and Experimental Design}

The seeds of fonio were treated with colchicine via soaking for four hours in four different colchicine concentrations $(0.1 \mathrm{mM}, 0.5 \mathrm{mM}, 1.0 \mathrm{mM}$ and $2.0 \mathrm{mM})$ while the controls $(0.0 \mathrm{mM})$ were soaked in distilled water. The colchicine treated seeds were washed thoroughly in running tap water for 4 hours, allowed to dry overnight and sown in the field plots along with the control. The treated seeds of both the accessions were sown along with respective controls $10 \mathrm{~cm}$ between stands and $20 \mathrm{~cm}$ between accessions and blocks. The seeds were planted in a Completely Randomized Block Design (CRBD) in a factorial arrangement with three replications. All the recommended agronomic and cultural practices such as planting, fertilizer application, weeding and thinning as well as harvesting methodologies were done according to the procedures described by NAERLS (2012) to raise a good crop.

\section{Statistical Analysis}

Based on the observations recorded on quantitative traits of both the five accessions of fonio were subjected to Analysis of variance (ANOVA) using SAS (2002) Version 9.1. Duncan's multiple range tests (DMRT) was used to separate the means.

\section{RESULTS}

The result for the Multivariate analysis of variance of the effects of various colchicine concentrations on the agronomic traits of five accessions of fonio is presented in Table 1 . The result showed highly significant difference $(P \leq 0.01)$ in the effects of colchicine concentrations on all the selected agronomic traits of fonio. Similarly, highly significant difference $(P \leq 0.01)$ was found among the accessions in terms of seedlings height, leaf area, spikes length, and number of seeds/spike. Significant difference $(P \leq 0.05)$ was found among the accessions in terms of height at maturity (Table 1).

However, the result of the mean effects of various colchicine concentrations on some selected traits of fonio (Table 2) indicated highest germination percents among $0.1 \mathrm{mM}$ colchicine treated mutants $(88.57 \%$ after one week of planting). Similarly, seedlings height $(4.64 \mathrm{~cm})$, survival rate $(74.00 \%)$ and height at maturity $(83.93 \mathrm{~cm})$ were found to be higher among 0.1 $\mathrm{mM}$ colchicine treated mutants. More so, the mutants treated with $0.1 \mathrm{mM}$ colchicine concentration produced 14 leaves that were larger in size $\left(13.15 \mathrm{~cm}^{2}\right)$ and produced highest number of tillers. The mutants $(0.1$ $\mathrm{mM}$ colchicine treated) produced highest number of spikes (7 spikes) that were $10.43 \mathrm{~cm}$ long and which produce the highest number of seeds (104seeds/spike). The 1000 seeds of these mutants weigh $0.63 \mathrm{~g}$. The effect of colchicine is concentration dependent, increase with decrease in colchicine concentration.

Furthermore, the mean effect of various colchicine concentrations on individual accessions of fonio is presented in Table 3 . The result showed that in accession Dinat, highest percentage germination of $89.63 \%$ was found among $0.1 \mathrm{mM}$ colchicine treated plants after one week of planting. The $0.1 \mathrm{mM}$ treated plants were found to be superior in terms of the remaining growth components such as seedlings height $(4.63 \mathrm{~cm})$, survival rate $(76.33 \%)$, height at maturity $(80.00 \mathrm{~cm})$, leaf number (15 leaves/plant) and size $\left(14.07 \mathrm{~cm}^{2}\right)$. Similarly, the yield attributes such as number of tillers (18 tillers), number of spikes (8 spikes), spikes length $(11.43 \mathrm{~cm})$, number of seeds/spike (98 seeds/spike) and 1000 seeds weight $(0.64 \mathrm{~g})$ were found to be higher among the $0.1 \mathrm{mM}$ treated mutants. The effect is concentration dependent, decrease with increase in colchicine concentrations. 
Bajopas Volume 10 Number 2 December, 2017

Table 1: Mean Squares for the Effects of Colchicine on the Agronomic Traits of Fonio

\begin{tabular}{|c|c|c|c|c|c|c|c|c|c|c|c|c|}
\hline $\begin{array}{l}\text { Sources of } \\
\text { Variation }\end{array}$ & Df & $\begin{array}{l}\text { \%Germ } \\
\text { (1 WAP) }\end{array}$ & $\begin{array}{l}\text { Seedlings } \\
\text { Height } \\
(\mathrm{cm})\end{array}$ & $\begin{array}{c}\% \\
\text { Survival }\end{array}$ & $\begin{array}{l}\text { Height at } \\
\text { Maturity } \\
(\mathrm{cm})\end{array}$ & $\begin{array}{c}\text { Leaves } \\
\text { No }\end{array}$ & $\begin{array}{l}\text { Leaf } \\
\text { Area } \\
\left(\mathrm{cm}^{2}\right)\end{array}$ & $\begin{array}{l}\text { No of } \\
\text { Tillers }\end{array}$ & $\begin{array}{l}\text { No of } \\
\text { Spikes }\end{array}$ & $\begin{array}{l}\text { Spikes } \\
\text { Length } \\
(\mathrm{cm})\end{array}$ & $\begin{array}{c}\text { No of } \\
\text { Seeds/Spike }\end{array}$ & $\begin{array}{c}1000 \\
\text { Seeds } \\
\text { Weight } \\
\text { (g) }\end{array}$ \\
\hline Concentration & 4 & $880.25 * *$ & $1.12^{* *}$ & $347.35 * *$ & $244.09 * *$ & $153.92 * *$ & $\begin{array}{c}88.21 \\
* *\end{array}$ & $72.58 * *$ & $19.55 * *$ & $14.26 * *$ & $3790.89 * *$ & $0.009 * *$ \\
\hline Acce & 4 & $100.46^{\text {ns }}$ & $0.32 * *$ & $89.75^{\mathrm{ns}}$ & 26.2 & $1.29^{\mathrm{ns}}$ & $27.48^{* *}$ & $4.28^{\mathrm{ns}}$ & $4.35^{\mathrm{ns}}$ & 6.0 & $1481.49 * *$ & $0.00004^{\mathrm{ns}}$ \\
\hline $\begin{array}{l}\text { Concentration } \\
\text { x Accession }\end{array}$ & 8 & $26.27^{\mathrm{ns}}$ & $0.06^{\text {ns }}$ & $9.47^{\mathrm{ns}}$ & $3.25^{\mathrm{ns}}$ & $0.94^{\mathrm{ns}}$ & $1.92^{\mathrm{ns}}$ & $0.72^{\mathrm{ns}}$ & $0.64^{\mathrm{ns}}$ & $0.53^{\text {ns }}$ & $75.49 * *$ & $0.00003^{\text {ns }}$ \\
\hline Error & 16 & 30.08 & 0.04 & 25.61 & 3.96 & 0.57 & 0.52 & 2.95 & 1.17 & 0.18 & 10.61 & 0.0001 \\
\hline
\end{tabular}

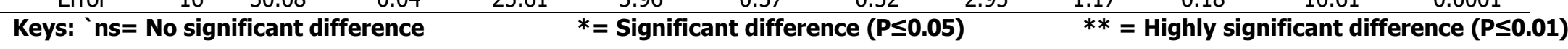

Table 2: Mean Effects of Different Colchicine Concentrations on Agronomic Traits of Fonio

\begin{tabular}{|c|c|c|c|c|c|c|c|c|c|c|c|}
\hline $\begin{array}{l}\text { Concentration } \\
(\mathrm{mM})\end{array}$ & $\begin{array}{l}\text { \%Germination } \\
\text { (1 WAP) }\end{array}$ & $\begin{array}{l}\text { Seedlings } \\
\text { Height }(\mathrm{cm})\end{array}$ & $\begin{array}{c}\% \\
\text { Survival }\end{array}$ & $\begin{array}{l}\text { Height at } \\
\text { Maturity } \\
(\mathrm{cm})\end{array}$ & $\begin{array}{l}\text { No of } \\
\text { Leaves }\end{array}$ & $\begin{array}{l}\text { Leaf } \\
\text { Area } \\
\left(\mathrm{cm}^{2}\right)\end{array}$ & $\begin{array}{l}\text { No of } \\
\text { Tillers }\end{array}$ & $\begin{array}{l}\text { No of } \\
\text { Spikes }\end{array}$ & $\begin{array}{l}\text { Spikes } \\
\text { Length } \\
(\mathrm{cm})\end{array}$ & $\begin{array}{c}\text { No of } \\
\text { Seeds/Spike }\end{array}$ & $\begin{array}{c}1000 \\
\text { Seeds } \\
\text { Weight }(\mathrm{g})\end{array}$ \\
\hline 0 & $69.63^{d^{* 1} 1}$ & $3.95^{c}$ & $62.47^{c}$ & $73.20^{d}$ & $5.40^{d}$ & $6.82^{d}$ & $13.40^{d}$ & $3.80^{c}$ & $7.88^{\mathrm{e}}$ & $63.87^{e}$ & $0.56^{\mathrm{e}}$ \\
\hline 0.1 & $88.57^{a}$ & $4.64^{a}$ & $74.00^{\mathrm{a}}$ & $83.93^{a}$ & $14.06^{\mathrm{a}}$ & $13.15^{\mathrm{a}}$ & $19.27^{a}$ & $6.93^{a}$ & $10.43^{a}$ & $104.20^{\mathrm{a}}$ & $0.63^{a}$ \\
\hline 0.5 & $82.61^{b}$ & $4.59^{a}$ & $69.60^{b}$ & $81.73^{b}$ & $11.80^{\mathrm{b}}$ & $11.96^{\mathrm{b}}$ & $17.87^{b}$ & $6.00^{\mathrm{b}}$ & $9.80^{\mathrm{b}}$ & $99.00^{\mathrm{b}}$ & $0.61^{b}$ \\
\hline 1.0 & $77.39^{c}$ & $4.37^{b}$ & $67.07^{b}$ & $80.27^{c}$ & $11.27^{\mathrm{b}}$ & $11.61^{\mathrm{cb}}$ & $16.86^{\mathrm{cb}}$ & $5.67^{b}$ & $9.15^{\mathrm{c}}$ & $93.07^{c}$ & $0.60^{c}$ \\
\hline 2.0 & $72.40^{d}$ & $4.27^{b}$ & $62.93^{c}$ & $79.00^{c}$ & $10.27^{c}$ & $11.35^{c}$ & $16.00^{c}$ & $5.4^{b}$ & $8.76^{\mathrm{d}}$ & $83.33^{d}$ & $0.59^{d}$ \\
\hline Mean & 78.12 & 4.36 & 67.21 & 79.63 & 10.56 & 10.98 & 16.68 & 5.56 & 9.20 & 88.69 & 0.60 \\
\hline $\operatorname{S.E}( \pm)$ & 5.48 & 0.19 & 5.06 & 1.99 & 0.76 & 0.72 & 1.72 & 1.08 & 0.42 & 3.26 & 0.01 \\
\hline
\end{tabular}

N.B: $*^{1}$ Means within the columns with the same superscript letter(s) are not significantly different (P $\left.\leq 0.05\right)$ 
Bajopas Volume 10 Number 2 December, 2017

Table 3: Mean Effect of Colchicine on Agronomic Traits of Fonio Accessions

\begin{tabular}{|c|c|c|c|c|c|c|c|c|c|c|c|c|}
\hline Accession & $\begin{array}{l}\text { Concentration } \\
(\mathrm{mM})\end{array}$ & $\begin{array}{l}\text { \%Germination } \\
\text { (1 WAP) }\end{array}$ & $\begin{array}{l}\text { Seedlings } \\
\text { Height } \\
(\mathrm{cm})\end{array}$ & $\begin{array}{c}\% \\
\text { Survival }\end{array}$ & $\begin{array}{l}\text { Height } \\
\text { at } \\
\text { Maturity } \\
(\mathrm{cm})\end{array}$ & $\begin{array}{l}\text { No of } \\
\text { Leaves }\end{array}$ & $\begin{array}{l}\text { Leaf } \\
\text { Area } \\
\left(\mathrm{cm}^{2}\right)\end{array}$ & $\begin{array}{l}\text { No of } \\
\text { Tillers }\end{array}$ & $\begin{array}{l}\text { No of } \\
\text { Spikes }\end{array}$ & $\begin{array}{l}\text { Spikes } \\
\text { Length } \\
(\mathrm{cm})\end{array}$ & $\begin{array}{c}\text { No of } \\
\text { Seeds/Spike }\end{array}$ & $\begin{array}{c}1000 \\
\text { Seeds } \\
\text { Weight } \\
(\mathrm{g})\end{array}$ \\
\hline \multirow{5}{*}{ Dinat } & 0 & $69.96^{\mathrm{d}^{* 1}}$ & $4.03^{d}$ & $63.00^{d}$ & $72.67^{d}$ & $4.66^{\mathrm{e}}$ & $5.00^{d}$ & $13.00^{d}$ & $4.00^{d}$ & $8.96^{\mathrm{e}}$ & $62.66^{\mathrm{e}}$ & $0.57^{e}$ \\
\hline & 0.1 & $89.63^{a}$ & $4.63^{a}$ & $76.33^{a}$ & $80.00^{\mathrm{a}}$ & $15.00^{\mathrm{a}}$ & $14.07^{\mathrm{a}}$ & $17.67^{\mathrm{a}}$ & $7.66^{a}$ & $11.43^{a}$ & $98.00^{\mathrm{a}}$ & $0.64^{\mathrm{a}}$ \\
\hline & 0.5 & $81.37^{\mathrm{b}}$ & $4.40^{\mathrm{b}}$ & $71.00^{\mathrm{b}}$ & $78.66^{\mathrm{b}}$ & $12.00^{\mathrm{b}}$ & $13.13^{b}$ & $16.66^{\mathrm{b}}$ & $6.00^{\mathrm{b}}$ & $10.50^{b}$ & $94.33^{b}$ & $0.62^{b}$ \\
\hline & 1.0 & $78.07^{c}$ & $4.23^{c}$ & $69.00^{c}$ & $79.00^{\mathrm{b}}$ & $11.33^{\mathrm{C}}$ & $12.53^{\mathrm{C}}$ & $16.65^{\mathrm{b}}$ & $5.33^{c}$ & $9.46^{c}$ & $91.00^{c}$ & $0.61^{c}$ \\
\hline & 2.0 & $78.46^{c}$ & $4.07^{d}$ & $62.33^{d}$ & $76.66^{c}$ & $9.66^{d}$ & $12.26^{\mathrm{C}}$ & $16.00^{c}$ & $5.66^{c}$ & $9.03^{d}$ & $84.33^{d}$ & $0.59^{d}$ \\
\hline \multirow{4}{*}{ Jakah } & 0.1 & $85.36^{a}$ & $4.33^{b}$ & $73.00^{\mathrm{a}}$ & $85.00^{\mathrm{a}}$ & $14.00^{\mathrm{a}}$ & $10.17^{a}$ & $19.00^{\mathrm{a}}$ & $5.33^{\mathrm{b}}$ & $9.93^{a}$ & $115.66^{a}$ & $0.63^{\mathrm{a}}$ \\
\hline & 0.5 & $82.76^{\mathrm{b}}$ & $4.40^{a}$ & $66.33^{b}$ & $81.66^{\mathrm{b}}$ & $12.33^{b}$ & $9.53^{b}$ & $18.33^{b}$ & $5.00^{c}$ & $9.66^{b}$ & $114.33^{b}$ & $0.61^{b}$ \\
\hline & 1.0 & $80.36^{c}$ & $4.40^{a}$ & $65.00^{\mathrm{b}}$ & $80.33^{c}$ & $11.67^{c}$ & $9.63^{b}$ & $16.33^{c}$ & $5.66^{\mathrm{a}}$ & $9.23^{c}$ & $104.33^{c}$ & $0.60^{C}$ \\
\hline & 2.0 & $69.80^{d}$ & $4.30^{\mathrm{b}}$ & $60.33^{d}$ & $79.67^{d}$ & $10.66^{d}$ & $9.23^{c}$ & $15.66^{\mathrm{d}}$ & $4.66^{d}$ & $8.80^{d}$ & $101.00^{d}$ & $0.59^{d}$ \\
\hline \multirow{5}{*}{ Jiw 1} & 0 & $68.17^{d}$ & $3.97^{e}$ & $59.00^{c}$ & $72.00^{\mathrm{e}}$ & $6.33^{d}$ & $8.37^{d}$ & $14.66^{\mathrm{e}}$ & $4.67^{d}$ & $7.83^{\mathrm{e}}$ & $57.66^{\mathrm{e}}$ & $0.56^{\mathrm{e}}$ \\
\hline & 0.1 & $86.26^{a}$ & $4.76^{a}$ & $71.33^{a}$ & $85.66^{a}$ & $13.67^{\mathrm{a}}$ & $14.26^{\mathrm{a}}$ & $20.00^{\mathrm{a}}$ & $7.33^{a}$ & $10.40^{a}$ & $102.66^{a}$ & $0.62^{a}$ \\
\hline & 0.5 & $80.76^{\mathrm{b}}$ & $4.63^{b}$ & $65.66^{\mathrm{b}}$ & $82.33^{\mathrm{b}}$ & $11.33^{\mathrm{b}}$ & $13.16^{\mathrm{b}}$ & $18.66^{\mathrm{b}}$ & $6.66^{\mathrm{b}}$ & $9.26^{\mathrm{b}}$ & $94.66^{b}$ & $0.61^{b}$ \\
\hline & 1.0 & $69.16^{\mathrm{C}}$ & $4.40^{c}$ & $64.33^{b}$ & $81.00^{C}$ & $11.66^{\mathrm{b}}$ & $12.93^{C}$ & $17.32^{\mathrm{C}}$ & $5.66^{c}$ & $8.46^{c}$ & $89.66^{c}$ & $0.60^{c}$ \\
\hline & 2.0 & $69.56^{\mathrm{c}}$ & $4.17^{d}$ & $59.66^{c}$ & $79.67^{d}$ & $10.33^{c}$ & $12.43^{c}$ & $16.67^{d}$ & $5.33^{c}$ & $8.26^{d}$ & $80.33^{d}$ & $0.59^{d}$ \\
\hline \multirow{4}{*}{ Jiw 2} & 0.1 & $90.83^{a}$ & $4.80^{\mathrm{b}}$ & $72.33^{a}$ & $85.00^{\mathrm{a}}$ & $13.33^{\mathrm{a}}$ & $12.63^{\mathrm{a}}$ & $19.67^{\mathrm{a}}$ & $8.66^{a}$ & $10.80^{a}$ & $109.00^{a}$ & $0.63^{\mathrm{a}}$ \\
\hline & 0.5 & $83.80^{b}$ & $4.90^{a}$ & $71.00^{\mathrm{b}}$ & $84.33^{b}$ & $11.00^{\mathrm{b}}$ & $11.20^{\mathrm{b}}$ & $17.00^{\mathrm{b}}$ & $5.66^{\mathrm{b}}$ & $10.70^{b}$ & $107.00^{b}$ & $0.61^{b}$ \\
\hline & 1.0 & $81.40^{c}$ & $4.66^{c}$ & $70.00^{c}$ & $80.33^{c}$ & $10.33^{c}$ & $10.93^{c}$ & $17.00^{\mathrm{b}}$ & $5.66^{\mathrm{b}}$ & $10.13^{c}$ & $107.00^{b}$ & $0.60^{c}$ \\
\hline & 2.0 & $75.87^{d}$ & $4.66^{c}$ & $65.33^{d}$ & $80.00^{c}$ & $10.00^{c}$ & $10.46^{\mathrm{C}}$ & $16.00^{\mathrm{C}}$ & $5.60^{c}$ & $9.83^{d}$ & $86.66^{c}$ & $0.60^{d}$ \\
\hline \multirow{5}{*}{ Nkpowas } & 0 & $66.17^{e}$ & $3.83^{d}$ & $66.33^{c}$ & $73.66^{\mathrm{e}}$ & $5.33^{\mathrm{e}}$ & $7.73^{c}$ & $13.33^{\mathrm{e}}$ & $4.33^{d}$ & $7.17^{d}$ & $59.33^{\mathrm{e}}$ & $0.56^{d}$ \\
\hline & 0.1 & $90.76^{a}$ & $4.66^{a}$ & $77.00^{\mathrm{a}}$ & $84.00^{\mathrm{a}}$ & $14.33^{\mathrm{a}}$ & $14.63^{\mathrm{a}}$ & $20.00^{\mathrm{a}}$ & $7.66^{a}$ & $9.56^{a}$ & $95.66^{\mathrm{a}}$ & $0.63^{a}$ \\
\hline & 0.5 & $84.37^{b}$ & $4.57^{b}$ & $74.00^{\mathrm{b}}$ & $81.67^{b}$ & $12.33^{\mathrm{b}}$ & $12.76^{\mathrm{b}}$ & $18.00^{\mathrm{b}}$ & $6.67^{b}$ & $8.86^{b}$ & $84.67^{b}$ & $0.62^{\mathrm{b}}$ \\
\hline & 1.0 & $77.96^{c}$ & $4.13^{c}$ & $67.00^{c}$ & $80.66^{c}$ & $11.33^{\mathrm{C}}$ & $12.20^{\mathrm{b}}$ & $17.00^{c}$ & $6.00^{\mathrm{b}}$ & $8.43^{b}$ & $73.33^{c}$ & $0.60^{c}$ \\
\hline & 2.0 & $68.30^{d}$ & $4.16^{c}$ & $67.00^{c}$ & $79.00^{d}$ & $10.66^{\mathrm{d}}$ & $12.36^{\mathrm{b}}$ & $15.67^{d}$ & $5.67^{c}$ & $7.86^{c}$ & $64.33^{d}$ & $0.59^{c}$ \\
\hline
\end{tabular}

N.B: $*^{1}$ Means within the columns with the same superscript letter(s) are not significantly different (P $\left.\leq 0.05\right)$ 
Similarly, in accession Jakah (Table 3), high germination percents were found among $0.1 \mathrm{mM}$ colchicine treated mutants after one week of planting (85.36\%). The result also showed that $0.1 \mathrm{mM}$ colchicine treated plants produced taller plants (at seedlings stage with $4.33 \mathrm{~cm}$ and matured stages with $85.00 \mathrm{~cm}$ ) having higher survival rate of of $73.00 \%$. Similarly, high numbers of leaves (14leaves/plant) that were larger in size (10.17 $\mathrm{cm}^{2}$ ) were found among the $0.1 \mathrm{mM}$ colchicine treated mutants. The colchicine treated mutants were found to produce 16 to 19 tillers with 5-6 spikes that are 8.80$9.93 \mathrm{~cm}$ long and which bear 101-115 seeds/spike. The 1000 mutant seeds weigh 0.59-0.63 g.

However, in the colchicine treated mutants of Jiw 1 (Table 3), high germination percents of $86.26 \%$ were found after one week of planting among $0.1 \mathrm{mM}$ treated plants. The mutants were found to be $4.17-4.76 \mathrm{~cm}$ at seedlings stage with a survival rate of $59.66-71.33 \%$. But at maturity, the mutants were found to be 79.67$85.66 \mathrm{~cm}$ in height. More so, high numbers of leaves (10-14leaves/plant) that were larger in surface area (12.43-14.26 $\mathrm{cm}^{2}$ ) are found among the colchicine treated plants. Similarly, the mutants produced high number of tillers (17-20 tillers) with 5-7 spikes that were longer $(8.26-10.40 \mathrm{~cm})$ and which bore $80-103$ seeds/spike. The 1000 mutant seeds were $0.59-0.62 \mathrm{~g}$. The effects are concentration dependent, decrease with increase in concentration.

Furthermore, the colchicine induced mutants of Jiw 2 (Table 3) produced higher germination percentage after one week of planting (75.87-90.83\%). Similarly, the mutants were taller in stature at both seedlings stage $(4.66-4.80 \mathrm{~cm})$ and matured stage $(80.00-85.00 \mathrm{~cm})$ with a range of survival rate from $65.33-72.33 \%$. More so, the mutants produced $10-13$ leaves that were $10.46-$
$12.63 \mathrm{~cm}^{2}$. Similarly, the number of tillers, number of spikes produced and the spikes lengths were higher among the colchicine induced mutants of Jiw 2 (16-20 tillers, 6-9 spikes that were 9.83-10.80 cm long respectively). About $87-109$ seeds were produced among the colchicine induced mutants of Jiw 2. The 1000 seeds weights of the mutants were $0.60-0.63 \mathrm{~g}$.

More so, the colchicine induced mutants of Nkpowas (Table 3) showed that, the mutants have high germination percents after one week of planting (68.30$90.76 \%$ ). The mutants were higher in stature at both seedlings stage $(4.16-4.66 \mathrm{~cm})$ and matured stage $(79.00-84.00 \mathrm{~cm})$ with a survival rate of $67.00-77.00 \%$. The number of leaves and the leaf area of the mutants were higher than that of the controls 11-14 leaves that were $12.36-14.63 \mathrm{~cm}^{2}$. Similarly, the mutants produced high number of tillers (16-20 tillers) with high number of spikes (6-8 spikes) that were longer $(7.86-9.56 \mathrm{~cm})$ and which produced higher number of seeds (64-96 seeds/spike). The mutant seeds were found to weigh higher than the controls (0.59-0.63 g).

However, the result for the mean responses of the five fonio accessions to colchicine treatment is presented in Table 4. The result showed that, Dinat shows high response to colchicine treatments with respect to number of spikes and spikes length. But Jakah shows high response to colchicine treatments in terms of leaves and seeds number. More so, high response to colchicine treatments in terms of leaf number and size, number of tillers, and number of spikes were found among accession Jiw 1. Furthermore, Jiw 2 was found to show better response to colchicine treatments in terms of seedlings height and spikes length while Nkpowas showed high response in terms of survival percents, leaves and spikes number.

Table 4: Mean Response of Fonio Accessions to Colchicine Treatment

\begin{tabular}{cccccccccccc}
\hline Accession & $\begin{array}{c}\text { \%Germination } \\
(1 \text { WAP) }\end{array}$ & $\begin{array}{c}\text { Seedlings } \\
\text { Height } \\
(\mathrm{cm})\end{array}$ & $\begin{array}{c}\text { \% } \\
\text { Survival }\end{array}$ & $\begin{array}{c}\text { Height } \\
\text { at } \\
\text { Maturity } \\
(\mathrm{cm})\end{array}$ & $\begin{array}{c}\text { No of } \\
\text { Leaves }\end{array}$ & $\begin{array}{c}\text { Leaf } \\
\text { Area } \\
\left(\mathrm{cm}^{2}\right)\end{array}$ & $\begin{array}{c}\text { No of } \\
\text { Tillers }\end{array}$ & $\begin{array}{c}\text { No of } \\
\text { Spikes }\end{array}$ & $\begin{array}{c}\text { Spikes } \\
\text { Length } \\
(\mathrm{cm})\end{array}$ & $\begin{array}{c}\text { No of } \\
\text { Seeds/Spike }\end{array}$ & $\begin{array}{c}1000 \\
\text { Seeds } \\
\text { Weight } \\
(\mathrm{g})\end{array}$ \\
\hline Dinat & $79.50^{\mathrm{b}+1}$ & $4.27^{\mathrm{b}}$ & $68.33^{\mathrm{ba}}$ & $77.40^{\mathrm{b}}$ & $10.53^{\mathrm{ba}}$ & $11.40^{\mathrm{b}}$ & $16.00^{\mathrm{b}}$ & $5.73^{\mathrm{a}}$ & $9.88^{\mathrm{a}}$ & $86.07^{\mathrm{c}}$ & $0.60^{\mathrm{a}}$ \\
Jakah & $77.16^{\mathrm{bc}}$ & $4.27^{\mathrm{b}}$ & $65.60^{\mathrm{b}}$ & $79.87^{\mathrm{a}}$ & $10.73^{\mathrm{a}}$ & $8.83^{\mathrm{d}}$ & $16.47^{\mathrm{ba}}$ & $4.73^{\mathrm{b}}$ & $9.13^{\mathrm{b}}$ & $100.53^{\mathrm{a}}$ & $0.59^{\mathrm{a}}$ \\
Jiw 1 & $74,79^{\mathrm{c}}$ & $4.39^{\mathrm{b}}$ & $67.87^{\mathrm{b}}$ & $80.13^{\mathrm{a}}$ & $10.67^{\mathrm{a}}$ & $12.19^{\mathrm{a}}$ & $17.47^{\mathrm{a}}$ & $5.93^{\mathrm{a}}$ & $8.85^{\mathrm{b}}$ & $85.00^{\mathrm{c}}$ & $0.59^{\mathrm{a}}$ \\
Jiw 2 & $81.65^{\mathrm{a}}$ & $4.61^{\mathrm{a}}$ & $64.00^{\mathrm{c}}$ & $80.93^{\mathrm{a}}$ & $10.07^{\mathrm{b}}$ & $10.55^{\mathrm{c}}$ & $16.67^{\mathrm{ba}}$ & $5.33^{\mathrm{ba}}$ & $9.78^{\mathrm{a}}$ & $96.40^{\mathrm{b}}$ & $0.60^{\mathrm{a}}$ \\
Nkpowas & $77.51^{\mathrm{bc}}$ & $4.27^{\mathrm{b}}$ & $70.23^{\mathrm{a}}$ & $79.80^{\mathrm{a}}$ & $10.80^{\mathrm{a}}$ & $11.92^{\mathrm{ba}}$ & $16.80^{\mathrm{ba}}$ & $6.07^{\mathrm{a}}$ & $8.38^{\mathrm{c}}$ & $75.47^{\mathrm{d}}$ & $0.60^{\mathrm{a}}$ \\
Means & 78.12 & 4.36 & 67.21 & 79.63 & 10.56 & 10.98 & 16.68 & 5.56 & 9.20 & 88.69 & 0.60 \\
\hline
\end{tabular}

N.B: $*^{1}$ Means within the columns with the same superscript letter(s) are not significantly different ( $P \leq 0.05)$ 
Bajopas Volume 10 Number 2 December, 2017 DISCUSSION

In view of the excellent possibilities of improving the growth and yield of fonio, the effects of various colchicine concentrations were observed for the first time on fonio. The increase in germination percents among colchicine induced mutants of fonio signifies the ability of the mutagen to improve germination rates. This is in conformity with the work of Kumar and Mishra (2004) who reported decreased germination rate with increase in EMS concentrations in okra (Abelmoschus esculentus). Reduced germination percentage with increasing doses of gamma radiation has also been reported in Pinus by Thapa (2004), Rye by Akgun and Tosum (2004) and in Chickpea by Khan et al. (2005) and Toker et al. (2005).

This finding is in contrast to the work of Bird and Neuffer (1988) who reported reduction in the germinating rates in plants treated with mutagens. However, increased survival rates and plants heights at both seedlings and matured stage among the colchicine induced mutants of fonio with decrease in concentrations revealed the ability of the mutagen to induce cellular growth especially at the meristematic tissues. This finding is similar to that of Mensah et al. (2007) who reported that, there were dose related effects of mutagenic treatment on qualitative traits resulting in reductions in traits such as germination and survival percentages, plant height, number of fruit per plant, and the findings of Adamu (2004) where groundnut was treated with gamma rays; but is in contrast to the finding of Maluszynski et al. (2001) who reported decrease in plant height due to induced mutation in rice. The increased in leaf number and size of fonio mutants reported is in conformity with the work of Nura et al. (2011) who reported increased in leaf attributes among colchicine-induced mutants of sesame. Increased in yield components of fonio conforms to the previous reports by Khalil (2001) who reported increase in yield components for both fennel and black cumin. The increased in tillers, number of spikes, spikes length and number of seeds/spike were found among the colchicine induced mutants of fonio. This is in

\section{REFERENCES}

Adamu, A.K., Chung, S.S., and Abubakar, S. (2004): The effect of ionizing radiation (Gamma rays) on tomato (s.n.). Nigerian Journal of Experimental Biology, 5(2):185-193.

Adamu, A. K. (2004). Gamma rays (60CO) and thermal neutrons induced mutants in popcorn (Zea mays L. variety praecox sturt). Nigerian Journal of Scientific Research 4:52-63.

Adoukonou-Sagbadja, H., Dansi, A., Vodouhè, R., and Akpagana, K. (2006): Indigenous knowledge and traditional conservation of fonio millet (Digitaria exilis, D. iburua) in Togo. Biodiversity Conservation, 15:2379-2395. conformity with the work of Rachovska and Dimova (2000), Chowdhary and Das (2001), and Srivastava et al. (2011) in wheat. Results obtained from this study further show that all traits were affected significantly by treatment with Colchicine in fonio. However, these findings were contrary to the work of Zeerak (1990) who observed reduced yield in combined treatments of gamma rays and EMS in Solanum melongena L., and the findings of Pavadai and Dhanvel (2004) in soybeans, and Varshney (1997) in bread wheat due to chemical mutagenesis. Similarly, the increased in 1000 seeds weights of fonio mutants due to colchicine treatments is similar to the findings of Nura et al. (2013) who reported similar result among colchicine induced mutants of sesame.

\section{CONCLUSION}

Thus, it is concluded that lower colchicine concentration $(0.1 \mathrm{mM})$ played a significant role in improving growth and yield components of fonio and that accession Jiw 1 showed the highest response to colchicine treatment. This indicates that, chemical mutagenesis is a vital tool for the improvement of the growth and yield of economic plants. Thus, $0.1 \mathrm{mM}$ colchicine concentration and accession Jiw 1 were recommended for breeding programs.

\section{Contribution of Authors}

Nura, S conducted the experiment and drafted the manuscript, Adamu, A.K supervised and set the experimental design, Adelanwa supervised the work and coordinated data collection, Usman, I.S supervised the work and help in literature search while Shehu, K help in literature search and interpretation of the results.

\section{Conflict of Interest}

There is no conflict of Interest.

\section{Acknowledgements}

The authors wish to show their gratitude to the Department of Biological Sciences Ahmadu Bello University Zaria for the opportunity given to them to perform the experiment and Acha Research Department, NCRIBEN for their assistance.

Ahloowalia, B.S., and Maluszynski, M. (2001): Induced mutation: A new paradigm in plant breeding. Euphytica, 118:167-173.

Akgun, I., and Tosum, M., (2004): Agricultural and cytological characteristics of M1 perennial rye (Secale montanum Guss.) as effected by the application of different doses of gamma rays. Pakistan Journal of Biological Science, 7 (5), pp. 827-833.

Barikmo, I., and Ouattara, F. (2004): Food Composition Table for Mali. Oslo. Norway: Institut National de Recherche en Sante' Publique, Akershus University College.

Bird, R.M.C.K., and Neuffer, M.G. (1988): Induced mutations in Maize. Plant Breeding Reviews 5: 141-178. 
Bajopas Volume 10 Number 2 December, 2017

Chowdhary, and Das, P.K. (2001): Induced variability in protein content and quality in hexaploid wheat. J. Interacademicia, 1: 1-6.

Chukwu, O., and Abdul-kadir, A.J. (2008): Proximate Chemical Composition of Acha (Digitaria exilis and Digitaria iburua) Grains. Journal of Food Technology, 6 (5): 214-216.

CIRAD/French Agricultural Research Centre for International Development. (2004): Fonio: An African cereal crop. http//:www.cirad.fr/en. Accessed 14 July, 2015.

Haq, N., and Ogbe, F.D. (1995): Fonio (Digitaria exilis and Digitaria iburua). In: Cereals and pseudocereals, Chapman and Hall, London, 225-245pp.

IPGRI/International Plant Genetic Resources Institute (2004): Promoting fonio production in West and Central Africa through germplasm management and improvement of post harvest technology. Final report; http://www. underutilized-species.org. Retrieved January $18^{\text {th }}, 2015$.

Jideani, I.A. (1993): The characterisation of the proteins of acha (Digitaria exilis Stapf). A $\mathrm{Ph}$. D. Thesis (Unpublished), University of Leeds England. 1-108 pp.

Jideani, I.A., Owusu Apenten, R.K., and Muller, H.G. (1994): The effect of cooking on proteins of acha (Digitaria exilis) and durum wheat. Journal of the Science of Food and Agriculture, 65:465-476.

Jideani, I.A. (1999): Traditional and possible technological uses of Digitaria exilis (fonio) and Digitaria iburua (iburu): A review. Plant Foods and Human Nutrition, 54:363-374.

Jideani, V.A., and Podgorski, S.C. (2009): In vitro starch digestibility and glycemic property of acha (Digitaria exilis) porridge. Cereal Foods World Supplement, 54:A48.

Khalil, M.Y., El-Sherbeny, S.E., Hussein, M.S., (2001): Growth, yield and chemical constituents of some medicinal plants in relation to gamma irradiation. Egyptian Journal of Horticulture, 28(3):355-369.

Khan, S., Wani, M.R., Bhat, M., and Parveen, K. (2005): Induced chlorophyll mutations in chickpea (Cicer arietinum L.). Int. J. Agric. Biol., 7: 764-767.

Kumar, A., and Mishra, M.N. (2004): Effect of gamma-rays, EMS and NMU on germination, seedling vigour, pollen viability and plant survival in M1and $\mathrm{M} 2$ generation of Okra (Abelmoschus esculentus (L.) Moench). Advances in Plant Science, 17(1), pp. 295297.
Maluszynski, M. (1990): Gene manipulation in plant improvement. Vol. 2.

Mensah, J. K., Obadoni, B. O., Akomeah, P. A., Ikhajiagbe, B., and Ajibolu, J. (2007): The effects of sodium azide and colchicine treatments on morphological and yield traits of sesame seed (Sesamum indicum L.). African Journal of Biotechnology, 6(5): 534538.

NAERLS/National Agricultural Extension, Research and Liason Services (2012): Crop Production Training Manual for Agriculture Extension Workers. The U.S. Agency for International Development (USAID). 1-37 pp.

Naik, P.M., and Murthy, H.N. (2009): The effects of gamma and ethyl methane sulphonate treatments on agronomical traits of niger ( $G$. abyssinica Cass.). African Journal of Biotechnology, 8(18): 4459-4464.

Nura, S., Adamu, A.K., Mu'Azu, S., and Dangora, D.B. (2011): Effect of colchicine induced mutagenesis on growth and yield of sesame (Sesamum indicum L.). Bayero Journal of Pure and Applied Sciences, 4(1): 121 - 125.

Nura, S., Adamu, A.K., Mu'Azu, S., Dangora, D.B., and Fagwalawa, L.D. (2013): Morphological characterization of colchicine-induced mutants in sesame (Sesamum indicum L.). Journal of Biological Sciences, 13(4):277282.

Pavadai, P.,and Dhanavel, D. (2004): Effect of EMS, DES and colchicine treatment in soybean. Crop Research, 28 (1-3): 118-120.

Pulseglove, J.W. (1972): Tropical crops. Monocotyledons. Vol. I. Longmans publication.

Rachovska, G., and Dimova, D. (2000): Effect of sodium azide and gamma rays on $\mathrm{M}_{1}$ quantitative characteristics of the productivity and their connection with $\mathrm{M}_{2}$ mutation changes in winter common wheat. Rasteniev dni-Nauki, 37: 413-419.

Srivastava, P., Marker, S., Pandey, P., and Tiwari, D.K. (2011): Mutagenic Effects of Sodium Azide on the Growth and Yield Characteristics in Wheat (Triticum aestivum L. em. Thell.). Asian Journal of Plant Sciences, 10: 190-201.

Temple, V.J., and Bassa, J.D. (1991): Proximate chemical composition of fonio (Digitaria exilis) grain. Journal of Science, Food and Agriculture, 56:561-564.

Thapa, C.B. (2004): Effect of acute exposure of gamma rays on seed germination and seedling growth of Pinus kesiya Gord and $P$. wallichiana A.B. Jacks. Our Nature, 2, pp. 13-17. 
Toker, C., Uzen, B., Canci, H., and Ceylan, F.O (2005): Effects of gamma irradiation on the shoot length of Cicer seeds. Radiation Physics and Chemistry, 73, pp. 365-367.

Varshney, R.A., and Siddiqui, B.A. (1997): Effects of thiourea in $M_{1}$ generation of bread wheat (Triticum aestivum L.). Journal of Indian Botanical Society, 76:165-168.
Vietmeyer, N.D., Borlaugh, N.E., Axtell, J., Burton, G.W., Harlan, J.R., and Rachie, K.O. (1996): Fonio (Acha). In: Vietmeyer ND, editor. Lost Crops of Africa. BOSTID, National Academic Press, Washington, DC, USA.

Zeerak, N.A. (1990): Induced morphological variants in Brinjal (Solanum melongena L.). Phytomorphology, 40(3\&4): 251-256. 